\title{
Proximate Composition of Thai and Cambodian Ready-to-Eat Insects
}

\author{
N. T. Grabowski $\mathbb{D}^{1},{ }^{1}$ T. Chhay $\mathbb{D}^{2},{ }^{2}$ S. Keo, ${ }^{3}$ R. Lertpatarakomol ${ }^{D},{ }^{4}$ J. Kajaysri ${ }^{D},{ }^{5}$ K. Kang, ${ }^{3}$ \\ P. Miech, ${ }^{2}$ M. Plötz $\mathbb{D}{ }^{1}$ and J. Mitchaothai $\mathbb{D}^{6}$ \\ ${ }^{1}$ Institute of Food Quality and Food Safety, Hannover University of Veterinary Medicine (TiHo), Hannover, Germany \\ ${ }^{2}$ Livestock Development for Community Livelihood (LDC), Phnom Penh, Cambodia \\ ${ }^{3}$ Faculty of Veterinary Medicine, Royal University of Agriculture (RUA), Phnom Penh, Cambodia \\ ${ }^{4}$ Basic Veterinary and Animal Science Department, Faculty of Veterinary Medicine, \\ Mahanakorn University of Technology (MUT), Bangkok 10530, Thailand \\ ${ }^{5}$ Veterinary Science Clinic, Faculty of Veterinary Medicine, Mahanakorn University of Technology (MUT), Bangkok 10530, \\ Thailand \\ ${ }^{6}$ Department of Animal Production Technology and Fisheries, Faculty of Agricultural Technology, \\ King Mongkut's Institute of Technology Ladkrabang (KMITL), Bangkok 10520, Thailand
}

Correspondence should be addressed to N. T. Grabowski; nils.grabowski@tiho-hannover.de

Received 2 June 2021; Accepted 24 July 2021; Published 28 October 2021

Academic Editor: Ayon Tarafdar

Copyright (c) 2021 N. T. Grabowski et al. This is an open access article distributed under the Creative Commons Attribution License, which permits unrestricted use, distribution, and reproduction in any medium, provided the original work is properly cited.

Samples of ready-to-eat snacks based on Lethocerus indicus, Gymnogryllus vietnamensis, Tarbinskiellus portentosus, Teleogryllus mitratus, Bombyx mori, Omphisa fuscidentalis, and Cybister limbatus were purchased in Cambodia and Thailand, and their proximate chemical composition (including $\mathrm{Na}$ and $\mathrm{Cl}$ ) was analysed. Comparing the results with the few existing references from the literature (based on unprocessed specimens), marked differences occurred. This was expected as the insect chemical composition varies strongly intra- and interspecifically due to taxon, feeding, instar, and processing, among others. In general, the insects mainly consisted of fat ( 35 to $60 \%$ ) and protein ( 25 to $38 \%$ ), with 2 to $16 \%$ nitrogen-free extract, 2 to $15 \%$ fibre, 3 to $5 \%$ ashes, 0.4 to $1.6 \% \mathrm{Na}$, and 0.6 to $1.4 \% \mathrm{Cl}$ (dry matter base). In this way, this contribution adds to the compositional knowledge about traditional insect-based foodstuffs. The combination of high fat and protein with low carbohydrates makes them suitable to combat nutrition disorders.

\section{Introduction}

Nowadays, the world can be divided into countries with and without a tradition of entomophagy. Thailand and Cambodia clearly belong to the first set of countries, each with a large number of traditionally consumed species. In these countries, insects are typically consumed as a snack after having been spiced and deep-fried. The extent of information regarding the composition varies with the species $[1,2]$, and while data are typically based on unprocessed samples, actual nutritional data of ready-to-eat insects in these countries are, to our knowledge, scarce or even inexistent. Therefore, the aim of this contribution is to present proximal chemical analysis data to a selection of Cambodian and Thai insects in the way the consumer actually eats them.

\section{Materials and Methods}

Table 1 lists the sampled species. Insect samples were purchased on the occasion of the 2020 IFNext (bringing insect farming to the next level) project meeting in different places of Cambodia and Thailand, ranging from traditionally prepared insects (Lethocerus indicus, Tarbinskiellus portentosus, Bombyx mori, and Cybister limbatus) as sold in the local market of Skuon (Kampong Cham, Cambodia) to 
TABLE 1: Sampled species.

\begin{tabular}{|c|c|c|c|c|c|c|c|}
\hline Order & Family & Species & English & Thai & Khmer & Origin & $n=$ \\
\hline Hemiptera & Belostomatidae & Lethocerus indicus & Giant water bug & $\begin{array}{l}\text { แมลงดานา- } \\
\text { maengda na }\end{array}$ & 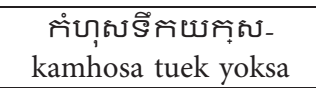 & KH (market) & 1 \\
\hline \multirow{3}{*}{ Orthoptera } & \multirow{3}{*}{ Gryllidae } & $\begin{array}{l}\text { Gymnogryllus } \\
\text { vietnamensis }\end{array}$ & $\begin{array}{l}\text { (Local field } \\
\text { cricket) }\end{array}$ & \multirow{3}{*}{$\begin{array}{c}- \\
\text { จิ้งโกร่ง-chìng } \\
\text { kròng } \\
\text { จิ้งหรีดทองแดง- } \\
\text { chìngrĭd thorng } \\
\text { daeng }\end{array}$} & - & $\begin{array}{l}\text { TH (farm } \\
\text { shop) }\end{array}$ & 2 \\
\hline & & $\begin{array}{l}\text { Tarbinskiellus } \\
\text { portentosus }\end{array}$ & $\begin{array}{l}\text { Short-tailed } \\
\text { cricket }\end{array}$ & & 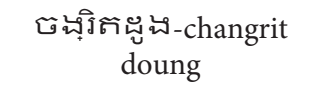 & KH (market) & 2 \\
\hline & & $\begin{array}{c}\text { Teleogryllus } \\
\text { mitratus }\end{array}$ & $\begin{array}{l}\text { (Local field } \\
\text { cricket) }\end{array}$ & & 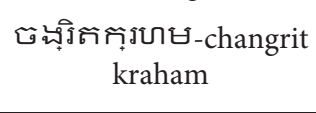 & $\mathrm{KH}$ (research) & 1 \\
\hline \multirow{2}{*}{ Lepidoptera } & Bombycidae & Bombyx mori & Silkworm pupa & $\begin{array}{c}\text { ดักแด้หหม-dàkdâe } \\
\text { măi }\end{array}$ & 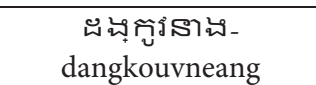 & KH (market) & 2 \\
\hline & Crambidae & $\begin{array}{c}\text { Omphisa } \\
\text { fuscidentalis }\end{array}$ & $\begin{array}{l}\text { Bamboo } \\
\text { caterpillar }\end{array}$ & $\begin{array}{l}\text { หนอนเยื่อไผ่- } \\
\text { nŏrngyùea phài }\end{array}$ & - & $\begin{array}{c}\mathrm{TH} \\
\text { (supermarket) }\end{array}$ & 1 \\
\hline Coleoptera & Dytiscidae & Cybister limbatus & $\begin{array}{c}\text { Predaceous } \\
\text { diving beetle }\end{array}$ & $\begin{array}{c}\text { แมลงตับเต่า- } \\
\text { maengda tàb tào }\end{array}$ & - & KH (market) & 1 \\
\hline
\end{tabular}

Names in parenthesis are generic names rather than colloquial species names; KH: Cambodia; TH: Thailand.

industrially processed and packaged Omphisa fuscidentalis purchased at a department store in Bangkok. Samples of Gymnogryllus vietnamensis were bought at a farm shop in Thâ Lùang (Lòpburi, Thailand), while the Teleogryllus mitratus sample was derived from the work of a $\mathrm{PhD}$ student at LDC in Phnom Penh. For the transport to Germany (as the analysis was planned to be carried out there), O. fuscidentalis and T. mitratus samples were milled in Phnom Penh, and all samples were kept as cool as possible using thermal packs. Upon arrival, samples were frozen at $-18^{\circ} \mathrm{C}$ (Liebherr Comfort NoFrost, LiebherrHausgeräte $\mathrm{GmbH}$, Ochsenhausen, Germany) until analysis. All samples but T. mitratus (dried only) and O. fuscidentalis were spiced and deep-fried. Skuon samples were spiced with soy sauce, chili, and pandan leaves, while G. vietnamensis was spiced in a Tôm Khà Gai (chicken galangal coconut soup) style, and O. fuscidentalis was prepared with salt, pepper, and soy sauce. Both commercial products (G. vietnamensis and O. fuscidentalis) claimed to be oil-free.

Species were identified, labeled, and submitted for proximate analysis (dry matter, ashes, crude protein, crude fat, crude fibre, nitrogen-free extract, $\mathrm{Na}$, and $\mathrm{Cl}$ ) following German standard procedures [3]. In this way, dry matter was obtained after drying the sample at $104^{\circ} \mathrm{C}$, ashes by combustion at $550^{\circ} \mathrm{C}$ until weight remained constant, crude fat by Soxhlet, crude protein by Kjeldahl, crude fibre after treatment with diluted acids and bases, and the nitrogen-free extract by subtracting the sum of the previous components from the dry matter value. Sodium was determined using atomic absorption spectroscopy and chlorine via colorimetric titration with silver nitrate. Samples' sizes allowed splitting the B. mori, G. vietnamensis, and T. portentosus samples into two individual batches $(n=2)$, but each sample was analysed in duplicate.

Romanisation for Khmer and Thai terms followed the recommendations of the Geographic Department of the Cambodian Ministry of Land Management and Urban Planning (GD (https://www.eki.ee/wgrs/rom1_km.pdf)) and the Royal Thai General System of Transcription (RTGS (https://www.orst.go.th/iwfm_splash.asp)), respectively. The latter was, however, expanded by using tone signs and transliterating the letter "อ" as "or" as done typically in Thailand.

However, original insect names were conserved to keep the information as precise as possible.

\section{Results}

Table 2 shows the complete results of the analysis, while Table 3 relates minimum and maximum values to different species. With values between approximately 660 and $980 \mathrm{~g} /$ $\mathrm{kg}$, all samples yielded relatively little moisture. Obviously, the more moisture the sample contained, the more pronounced the differences between the complete sample and the sample on a dry matter base were. In this way, ashes ranged approximately between 25 and $50 \mathrm{~g} / \mathrm{kg}$, crude protein between 200 and 530, crude fat between 320 and 600 , crude fibre between 40 and 140, nitrogen-free extract between 2 and 160, sodium (Na) between 3 and 16, and chlorine $(\mathrm{Cl})$ between 6 and $14 \mathrm{~g} / \mathrm{kg}$ (Table 1). While $L$. indicus values ranged between the extreme values, T. mitratus yielded the highest protein content and one of the lowest fat contents. Lowest protein contents were found in B. mori and G. vietnamensis, while O. fuscidentalis yielded most fat. C. limbatus turned out to be of low fat but high fibre. Most minerals were detected in T. portentosus and B. mori.

The manufacturer of the Thai commercial products included compositional data on their products' labels, using a serving base ( 20 or $25 \mathrm{~g}$ ). When transforming these values to a $100 \%$ base, the protein content of O. fuscidentalis was $24 \%$, fat $56 \%, \mathrm{~N}_{2}$-free extract $12 \%$, and fibre $4 \%$, and for G. vietnamensis, they were $35,35,15$, and $5 \%$, respectively. While most values for $O$. fuscidentalis largely corresponded with the results of the present paper, G. vietnamensis was lower in protein, but higher in fat and fibre. More fibre was also encountered in O. fuscidentalis. 


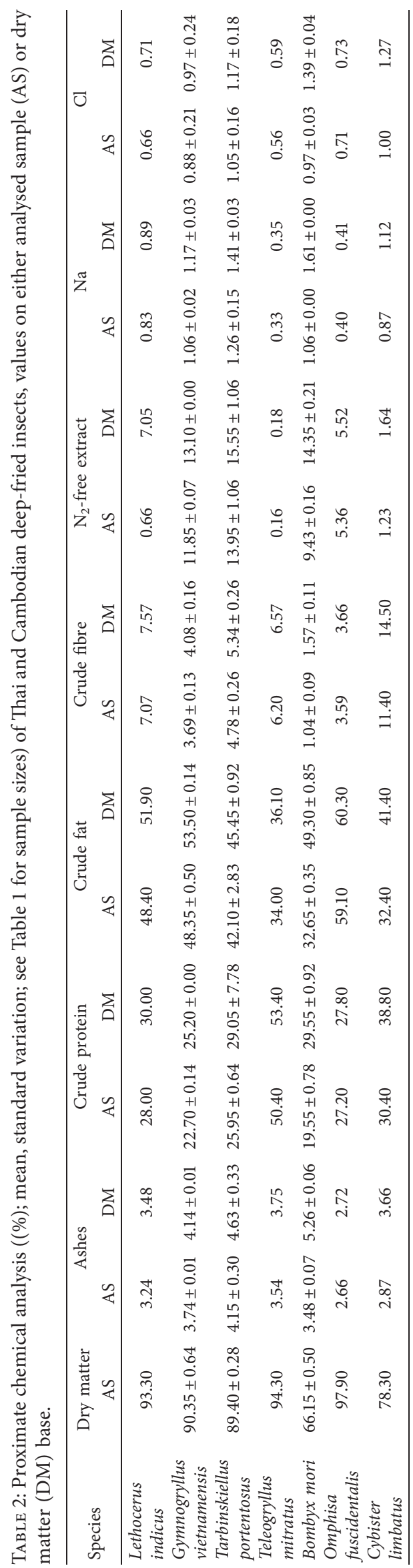


TABLE 3: Extreme values in relation to the insect species.

\begin{tabular}{|c|c|c|}
\hline Species & Minimum values & Maximum values \\
\hline Lethocerus indicus & None & None \\
\hline $\begin{array}{l}\text { Gymnogryllus } \\
\text { vietnamensis }\end{array}$ & Crude protein $(\mathrm{DM})$ & None \\
\hline $\begin{array}{l}\text { Tarbinskiellus } \\
\text { portentosus }\end{array}$ & None & $\begin{array}{c}\text { Ashes (AS), } \mathrm{N}_{2} \text {-free extract (AS, DM), Na (AS), } \\
\text { Cl (AS) }\end{array}$ \\
\hline Teleogryllus mitratus & $\begin{array}{l}\text { Crude fat (DM), } \mathrm{N}_{2} \text {-free extract (AS, DM), } \mathrm{Na}(\mathrm{AS}, \mathrm{DM}), \mathrm{Cl} \\
(\mathrm{AS}, \mathrm{DM})\end{array}$ & Crude protein (AS, DM) \\
\hline Bombyx mori & Dry matter (AS), crude protein (AS) & Ashes (DM), $\mathrm{Na}(\mathrm{DM}), \mathrm{Cl}(\mathrm{DM})$ \\
\hline Omphisa fuscidentalis & Ashes (AS, DM), crude fibre (AS, DM) & Dry matter (AS), crude fat (AS, DM) \\
\hline Cybister limbatus & Crude fat (AS) & Crude fibre (AS, DM) \\
\hline
\end{tabular}

\section{Discussion}

Even on the DM base, the chemical composition of the analysed insects was, as expected, heterogeneous. This variability is due to taxon, feeding, instar, trimming, and processing, among others [4]. Comparing results with the literature (Table 4) was unsatisfying since most references were based on nonprocessed insects. In addition, no data for G. vietnamensis could be found. The composition of the African cricket species "Gymnogryllus lucens" was documented by Magara et al. [5], but this species was moved to another genus, being currently termed as Phonarellus lucens in the Orthoptera Species File (https://orthoptera.speciesfile. org/Common/basic/Taxa.aspx?TaxonNameID=1122521, accessed on February $\left.17^{\text {th }}, 2021\right)$. As not all authors analysed for the same parameters, some table cells had to remain in blank.

Köhler et al. [6] determined crude protein in several Thai species including $B$. mori, reporting $26.6 \%$ in fresh weight when sampling deep-fried silkworms from a street vendor, which is slightly more than registered in the present study. The same is true for the sodium content (1.3\%). Yhoung-aree et al. [7] also analysed deep-fried O. fuscidentalis, recording $3.9 \%$ ash content, $26.70 \%$ protein, $55.80 \%$ fat, and $11.50 \%$ carbohydrates (DM), which largely corresponds to these results.

Lumsa-ed [8] analysed several species of Thai edible insects, among them also aquatic beetles. However, the predaceous diving beetles were identified only at the genus level (Cybister spp.). According to Ramos-Elorduy et al. [9], edible Cybister species listed for Thailand are C. limbatus, C. tripunctatus, and an unidentified species. The samples analysed by Lumsa-ed [8] yielded $63.28 \%$ moisture, $3.51 \%$ ash, $57.08 \%$ protein, $19.20 \%$ fat, $13.34 \%$ fibre, and $0.57 \%$ salt.

Data about specific minerals were even scarcer. Lumsaed [8] reported $0.65 \%$ salt in both $L$. indicus and T. mitratus, and Thapa [10] reported $609.2 \mathrm{mg}$ in O. fuscidentalis.

Table 4 also shows marked intraspecies variances, possibly due to analytical differences. Results for T. portentosus included both whole insects and degutted ones. In this way, differences between the present values and the references were expected.
Since Table 4 contains the reference for unprocessed samples and Table 2 the measured values of processed ones, the influence of processing can be estimated. This, however, can only be hypothesized because, on the one hand, the reference values vary strongly, and, on the other hand, the present contribution only measured processed insects rather than following the process chain from specific batches from raw to deep-fried. Still, it was seen that deep frying reduced moisture and protein, increased fat, and seemingly did not affect ash, fibre, nor carbohydrates. Moisture was reduced because of evaporation during frying, and protein may have abandoned the insect body during frying. In fact, personal observations while deep frying insects showed that, after a certain time, a dark sediment forms at the bottom of the frying pan or wok. Another explanation may be that the insects were cooked before deep frying. This also reduces protein and fat contents in the insects [4]. Unlike protein, fat is replaced during deep frying. For a statistical approach, differences between reference and measured values expressed as percentages were compared among each other using Student's $t$-test when possible (data not shown). Significant $(p<0.05)$ differences among species occurred for moisture but generally not for the other parameters. Due to gaps in the reference, not all species-parameter combinations could be evaluated. In this way, moisture was reduced between 58 (C. limbatus) and 92\% (T. mitratus). Some $19.78 \pm 22.32 \%$ protein was lost, while fat increased by $226.59 \pm 230.34 \%$.

Few data exist on the compositional changes of southeastern Asian insects during processing. Yhoung-aree [21] gathered protein and fat contents of raw, blanched, and fried L. indicus, T. portentosus, B. mori, O. fuscidentalis, and C. limbatus to a varying degree. Using these data for further calculation, it was seen that blanching reduced the protein content by approximately $30 \%$ (20\% in B. mori), while frying previously blanched insects resulted in an analytical increase by $15 \%$, probably due to water evaporation. Blanching raw insects reduced the fat content to a variable degree (to approximately $84 \%$ of the original amount in B. mori and to $48 \%$ in T. portentosus), and frying increased it for obvious reasons by approximately 123 to $171 \%$. This tendency was reflected in the present data as protein contents of the 
TABLE 4: Proximate chemical composition (\%, dry matter base; nonprocessed) of sampled species (or similar) according to [1, 5, 7, 8, 10-20].

\begin{tabular}{lcccccc}
\hline Species & Moisture & Ashes & Crude protein & Crude fat & Crude fibre & $\mathrm{N}_{2}$-free extract \\
\hline Lethocerus indicus & $51.75-64.47$ & $0.30-6.75$ & $41.63-67.31$ & $8.15-44.71$ & $1.36-22.07$ & $0-27.00$ \\
Tarbinskiellus portentosus* & $65.54-73.30$ & $2.33-9.36$ & $47.94-74.15$ & $19.50-30.32$ & $0.05-14.30$ & $3.97-11.86$ \\
Teleogryllus mitratus** & $67.81-71.84$ & $4.26-9.76$ & $46.76-58.37$ & $22.71-24.32$ & $7.17-7.58$ & 11.1 \\
Bombyx mori & $60.60-80.29$ & $2.70-8.60$ & $38.80-69.84$ & $8.09-35.00$ & $2.00-5.95$ & $1.00-29.50$ \\
Omphisa fuscidentalis & 60.00 & - & $25.5-38.25$ & 55.3 & - & - \\
Cybister limbatus & $47.10-61.20$ & $0.63-11.40$ & $42.60-54.24$ & $18.20-32.65$ & $10.80-16.26$ & $0.77-27.70$ \\
\hline
\end{tabular}

*Referred to as "Brachytrupes portentosus"; ** referred to as "Acheta testaceus" or "Acheta testacea."

processed insects were typically below the references in Table 4 and fat ranged high above them.

\section{Conclusions}

While some species of edible insects are well documented, many are not, particularly traditional ones and particularly in terms of foodstuffs derived from them. In this way, the present short communication sought to help filling gaps. Apart from natural factors (taxon, feeding, etc.), processing adds another dimension to compositional changes. While the values assessed as such do not reflect the references (based on unprocessed specimens), processing is responsible for protein and fat content changes. The tested species largely consisted of protein and fat (which are both very valuable nutrients), while carbohydrates were low. In contrast, potato crisps and other plant-based, deep-fried snacks typically contain more carbohydrates and fat rather than protein. This combination is beneficial for cases where nutrients have to be supplied to combat malnutrition as it is for the case where obesity is reduced by ketogenic diets.

\section{Data Availability}

The data used to support the findings of this study are available from the corresponding author upon request.

\section{Conflicts of Interest}

The authors declare that there are no conflicts of interest regarding the publication of this paper.

\section{Acknowledgments}

This project was supported by funds of the Federal Ministry of Food and Agriculture (BMEL) based on a Decision of the Parliament of the Federal Republic of Germany via the Federal Office for Agriculture and Food (BLE).

\section{References}

[1] P. Bophima, "Nutritional value of edible insects," M.S. thesis, p. 83, Khon Kaen University, Khon Kaen, Thailand, 2009.

[2] K. Hortle, R. Troueng, J. Garrison, and G. Cans, "Havesting insects-a growing industry in Cambodia," Catch and Culture, vol. 11, pp. 9-10, 2005.

[3] VDLUFA, "Die chemische untersuchung von futtermitteln. Methodenbuch band III," Loose-Leaf Collection, VDLUFAVerlag, Darmstadt, Germany, 2007.
[4] N. T. Grabowski, Speiseinsekten, Behr's, Hamburg, Germany, 2017.

[5] H. J. O. Magara, S. Niassy, M. A. Ayieko et al., "Edible crickets (Orthoptera) around the world: distribution, nutritional value, and other benefits-a review," Frontier in Nutrition, vol. 7, p. 23, Article ID 537915, 2020.

[6] R. Köhler, L. Kariuki, C. Lambert, and H. K. Biesalski, "Protein, amino acid and mineral composition of some edible insects from Thailand," Journal of Asia-Pacific Entomology, vol. 22, no. 1, pp. 372-378, 2019.

[7] J. Yhoung-aree, P. Puwastien, and G. A. Attig, "Edible insects in Thailand: an unconventional protein source?" Ecology of Food and Nutrition, vol. 36, pp. 133-149, 1997.

[8] C. Lumsa-ed, การศึกษาคุณคาทางอาหารของแมลงที่กินได้ทา งภาดใต้ตอนบน-A Study on the Nutrition Value of Edible Insects in Upper Southern Thailand-Research Report, Thailand Research Fund (TRF), Bangkok, Thailand, 1998.

[9] J. Ramos-Elorduy, J. M. P. Moreno, and V. H. M. Camacho, "Edible aquatic Coleoptera of the world with an emphasis on Mexico," Journal of Ethnobiology and Ethnomedicine, vol. 5, no. 1, p. 11, 2009.

[10] R. Thapa, Mass Rearing Of Bamboo Borer, Omphisa fuscidentalis (Lepidoptera; Pyralidae) For Eggs Ans Larvae Production For Sustainable Management And Utilization Of The Species, p. 24, Mae Fah Luang University, Chiang Rai, Thailand, 2008.

[11] N. N. Khin, Edible Insects from Hlegu and Taikkyi Townships, Yangon Region, University of Yangon, Department of Zoology, Yangon, Myanmar, 2016, https://meral.edu.mm/record/ 3009/files/Edible\%20insects\%20erom\%20Hlegu\%20and\% 20Taikkyi.pdf.

[12] U. Klinhom, C. Rasirattana, and S. Jitjamnong, An Investigation of Some Nutritive Values, Some Parasites and Some Toxic Components of Edible Insects in Northeastern Thailand. Thesis, p. 125, Srinakharinwirot University, Mahasarakham, Thailand, 1984.

[13] V. Melo Ruiz, C. Moreno Bonett, L. Sánchez Herrera, R. Díaz García, and C. Gazga Urioste, "Macronutrient composition of giant water bug (Lethocerus sp.) edible insect in Mexico and Thailand (sic!)," Journal of Agricultural Science and Technology A, vol. 6, pp. 349-354, 2016.

[14] S. Narzari, "Analysis of nutritional value and biochemical evaluation of proteins of wild edible insects consumed by the Bodos of selected areas of Assam," Thesis, 2017, http://hdl. handle.net/10603/206529.

[15] P. Raksakantong, N. Meeso, J. Kubola, and S. Siriamornpun, "Fatty acids and proximate composition of eight Thai edible terricolous insects," Food Research International, vol. 43, no. 1, pp. 350-355, 2010.

[16] B. A. Rumpold and O. K. Schlüter, "Nutritional composition and safety aspects of edible insects," Molecular Nutrition \& Food Research, vol. 57, no. 5, pp. 802-823, 2013.

[17] T. Shantibala, R. K. Lokeshwari, and H. Debaraj, "Nutritional and antinutritional composition of the five species of aquatic 
edible insects consumed in Manipur, India," Journal of Insect Science, vol. 14, p. 14, 2014.

[18] O. Sihamala, N. Saraboot, P. Chunthanom, and S. Bhulaidok, "คุณค่าทางโภชนาการของแมลงกินได้ในจังหวัดกาฬสินธุ-nutritional value of edible insects in Kalasin province," King Mongkut's Agricultural Journal, vol. 36, no. 2, pp. 98-105, 2018.

[19] A. D. Soren, K. Choudhury, P. J. Saprua, and D. Sarma, "Nutrient and toxic heavy metal assessment of Tarbinskiellus portentosus and Schizodactylus monstrosus consumed by the Bodo tribe in Assam," International Journal of Tropical Insect Science, vol. 6, 2021.

[20] P. Suangpuag and P. Puwastien, "Nutritive value of unconventional protein source: insect," Journal of Nutrition Association of Thailand, vol. 17, pp. 5-12, 1983.

[21] J. Yhoung-aree, "Edible insects in Thailand; nutritional values and health concerns," in Forest Insects as Food: Humans Bite Back. FAO-Regional Office for Asia and the Pacific, P. Durst, D. V. Johnson, R. N. Leslie, and K. Shono, Eds., Bangkok/ Thailand, 2010. 